\title{
MLHI mediates PARP-dependent cell death in response to the methylating agent $\mathrm{N}$-methyl-N-nitrosourea
}

\author{
JR McDaid ${ }^{1,4,5}$, J Loughery ${ }^{1,5}$, P Dunne ${ }^{1,5}$, JC Boyer², CS Downes ${ }^{3}$, RA Farber² and CP Walsh", \\ 'Stem Cells and Epigenetics Research Group, Centre for Molecular Biosciences, School of Biomedical Sciences, University of Ulster, Coleraine BT52 ISA, \\ Northern Ireland, UK; ${ }^{2}$ Department of Pathology and Laboratory Medicine, University of North Carolina at Chapel Hill, Chapel Hill, NC 27599, USA; \\ ${ }^{3}$ Cancer and Ageing Research Group, Centre for Molecular Biosciences, School of Biomedical Sciences, University of Ulster, Coleraine BT52 ISA, Northern \\ Ireland, UK
}

BACKGROUND: Methylating agents such as N-methyl-N-nitrosourea (MNU) can cause cell cycle arrest and death either via caspasedependent apoptosis or via a poly(ADP-ribose) polymerase (PARP)-dependent form of apoptosis. We wished to investigate the possible role of $\mathrm{MLHI}$ in signalling cell death through PARP.

METHODS: Fibroblasts are particularly dependent on a PARP-mediated cell death response to methylating agents. We used hTERTimmortalised normal human fibroblasts (WT) to generate isogenic MLHI-depleted cells, confirmed by quantitative PCR and western blotting. Drug resistance was measured by clonogenic and cell viability assays and effects on the cell cycle by cell sorting. Damage signalling was additionally investigated using immunostaining.

RESULTS: MLHI-depleted cells were more resistant to MNU, as expected. Despite having an intact $G_{2} / M$ checkpoint, the WT cells did not initially undergo cell cycle arrest but instead triggered cell death directly by PARP overactivation and nuclear translocation of apoptosis-inducing factor (AIF). The MLHI-depleted cells showed defects in this pathway, with decreased staining for phosphorylated $\mathrm{H} 2 \mathrm{AX}$, altered PARP activity and reduced AIF translocation. Inhibitors of PARP, but not of caspases, blocked AIF translocation and greatly decreased short-term cell death in both WT and MLHI-depleted cells. This MLHI-dependent response to MNU was not blocked by inhibitors of ATM/ATR or p53.

CONCLUSION: These novel data indicate an important role for MLHI in signalling PARP-dependent cell death in response to the methylating agent MNU.

British Journal of Cancer (2009) I 0 I, 44I-45I. doi:I0.I038/sj.bjc.6605 I 86 www.bjcancer.com

Published online 28 July 2009

(C) 2009 Cancer Research UK

Keywords: alkylating agent; caspase; p53; ATM/ATR

Mismatch repair (MMR) is an essential system for reducing postreplicative errors in DNA including base-base mispairs and small insertion/deletion loops due to polymerase slippage, and is conserved from bacteria to humans. In E. coli it consists of two key homodimeric proteins: MutS, which recognises and binds the mismatch, and MutL, which is recruited to the complex and initiates repair (Kunkel and Erie, 2005). In humans there are multiple homologues for each protein and they combine to form alternative repair complexes with slightly different specificities: MutS $\alpha$, a heterodimer of MSH2 and MSH6, can bind single base mismatches or insertion/deletion loops, whereas $\operatorname{MutS} \beta$, a heterodimer of MSH2 and MSH3 only binds to insertion/deletion loops (Kunkel and Erie, 2005). For somatic cells, the primary MutL complex is called MutL $\alpha$ and consists of a heterodimer of MLH1 and PMS2, which binds to MutS and initiates repair (Raschle et al, 2002). Excision of the damaged base and resynthesis involves

\footnotetext{
*Correspondence: Dr CP Walsh; E-mail: cp.walsh@ulster.ac.uk

${ }^{4}$ Current address: National Centre for Medical Genetics, Our Lady's Hospital, Crumlin, Dublin 12, Republic of Ireland

${ }^{5}$ These authors contributed equally to this work

Revised 16 June 2009; accepted 17 June 2009; published online 28 July 2009
}

participation of other proteins such as PCNA, EXO1 and DNA polymerases $\delta$ and $\varepsilon$ (Kunkel and Erie, 2005). In the absence of functional MMR, high rates of mutation are seen, particularly at microsatellite repeats, which can lead to inactivating frameshifts in mononucleotide runs within the coding regions of genes such as $B L M, B A X$ and IGFIIR, disrupting their function (Duval and Hamelin, 2002). This mutator phenotype also complicates the separation of primary and secondary effects of MLH1-deficiency.

Mutations or epigenetic silencing of MMR genes is associated with several human cancers. Lynch Syndrome, or hereditary nonpolyposis colorectal cancer, arises as a result of a primary defect in MMR genes, most commonly MLH1 and MSH2 (Peltomaki and Vasen, 2004); patients have a very high risk of developing colorectal and/or endometrial tumours and are at elevated risk for certain other types of tumours. Defects in MMR are also found in sporadic cancers of the colon, stomach, endometrium and ovary (Thibodeau et al, 1998). For most sporadic cancers, inactivation of MLH1 is usually associated with methylation of the promoter rather than mutation (Herman and Baylin, 2003). MMR-defective tumours can also arise in response to exposure to some cytotoxic agents, with microsatellite instability being reported in lung cancer in chromium-exposed workers (Hirose et al, 2002) and in glioblastomas after temozolomide treatment (Cahill et al, 2007). 
MMR proteins also participate in DNA damage signalling and MMR-deficient cells show resistance to a number of different classes of chemotherapeutic drugs (reviewed in O'Brien and Brown, 2006) such as the methylating agent $\mathrm{N}$-methyl- $\mathrm{N}$-nitrosourea (MNU), the cross-linking agent cisplatin and the antimetabolite 6-thioguanine (6TG). MLH1 has been shown to participate in signalling cell cycle arrest in response to 6TG and $\mathrm{MNU}$, or to the related methylating agent $N$-methyl- $N^{\prime}$-nitro- $N$-nitrosoguanidine (MNNG; Hawn et al, 1995; Buermeyer et al, 1999). For MNNG, MLH1 signals arrest in conjunction with the phosphatidylinositol 3-kinase-like kinases Ataxia telangiectasia mutated (ATM; Adamson et al, 2005) and ATM- and Rad3-related (ATR; Stojic et al, 2004). These kinases phosphorylate a number of targets in the cell in response to damage, such as the variant histone $\mathrm{H} 2 \mathrm{AX}$ and $\mathrm{p} 53$ (Lavin et al, 2005). Treatment of cells with MNNG (Yanamadala and Ljungman, 2003) also leads to stabilisation of p53 and subsequently triggers apoptosis through a caspase-mediated pathway, which is dependent on MLH1 (Hickman and Samson, 1999, 2004; Yanamadala and Ljungman, 2003). This pathway is primarily important in cells which are deficient in methylguanine methyltransferase (MGMT), indicating that the main cytotoxic lesion caused by the methylating agents is $0^{6}$-methylguanine (Hickman and Samson, 2004). More recently, MLH1 has been shown by Kinsella and co-workers to be important for signalling autophagy and inhibiting apoptosis in response to 6TG, a pathway that also requires p53 (Zeng et al, 2007). The damage signalling function of MLH1 has been shown to require higher levels of the protein than those needed to successfully maintain microsatellite stability, as cells with low levels of MLH1 show no increase in mutation rate but have lost the ability to signal cell cycle arrest in response to 6TG (Buermeyer et al, 1999) or MNNG (Buermeyer et al, 1999; Cejka et al, 2003; Stojic et al, 2004).

Methylating agents are in widespread use in chemotherapy, in part, due to their ability to kill apoptosis-resistant cells such as follicular lymphoma (Lister, 1991; Zong et al, 2004; Amaravadi and Thompson, 2007). Cells that express the oncogene $b c l-2$, a dominantnegative regulator of apoptosis, or which are deficient in the cellular homologues $B A K$ or $B A X$, are resistant to apoptosis through caspasemediated pathways (Danial, 2007). Methylating agents can trigger an alternative cell death pathway in Bax/Bak double mutant mouse fibroblast cells (Zong et al, 2004; Moubarak et al, 2007), or in cells overexpressing bcl-2 (Amaravadi and Thompson, 2007), involving poly(ADP-ribose) polymerase (PARP). PARP is a nuclear enzyme, which responds to DNA damage by adding 50-200 molecules of ADP-ribose to a variety of nuclear targets, including histones (Kim et al, 2005). PARP activation causes a rapid drop in nicotinamide adenine dinucleotide $(\mathrm{NAD}+)$ levels, triggering mitochondrial membrane depolarisation and translocation of apoptosis inducing factor (AIF) to the nucleus ( $\mathrm{Yu}$ et al, 2002, 2006). In the nucleus, AIF causes chromatin condensation and DNA fragmentation (Susin et al, 1999). However, little is known about the upstream signalling events which activate PARP in response to methylating damage.

Here we sought to address the possible role of MLH1 in caspaseindependent programmed cell death in response to methylating agents. We generated an isogenic system of normal human fibroblasts and derivatives, which are MLH1 depleted and resistant to MNU, but lack complications such as microsatellite instability and aneuploidy. We show here that the WT cells initially die almost exclusively by PARP-mediated cell death, and that this pathway is inhibited in cells with decreased levels of MLH1. These data uncover a new role for MLH1 in regulating a caspaseindependent, non-autophagic mechanism for cell killing.

\section{MATERIALS AND METHODS}

\section{Cell culture and drug treatment}

The colon cancer cell lines HCT116 and HCT116 + chromosome 3 $(\mathrm{HCT}+\mathrm{chr} 3)$ cells (Koi et al, 1994) were maintained in DMEM with $10 \%$ FBS; the latter were cultured with $400 \mu \mathrm{g} \mathrm{ml}^{-1} \mathrm{G} 418$ periodically to ensure retention of the extra chromosome 3 . The normal (WT) human fibroblast cell line hTERT-1604 (Ouellette et al, 2000) with a stably integrated $(\mathrm{CA})_{17}$ microsatellite repeat (Roques et al, 2001) and their MLH1-depleted derivatives (M1, M2, etc) were grown in high-glucose DMEM with $10 \%$ FBS and $2 \times$ non-essential amino acids, with hygromycin $\left(150 \mu \mathrm{g} \mu \mathrm{l}^{-1}\right)$ for the siRNA-containing cells. Selection was removed $48 \mathrm{~h}$ before any experimental analysis. For MNU (Sigma, Poole, UK) treatment, cells were pretreated with $25 \mu \mathrm{M} 0^{6}$-benzylguanine (BG; Sigma) to inactivate MGMT and BG was kept in the medium throughout. Other inhibitors were maintained in the media as follows: 3,4dihydro-5[4-(1-piperindinyl)butoxy]-1(2H)-isoquinoline (DPQ; Sigma) at a final concentration of $30 \mu \mathrm{M}$ (Yu et al, 2002); Boc-DFMK at $10 \mu \mathrm{M}$ (Hickman and Samson, 2004); caffeine at $2 \mathrm{~mm}$ (Stojic et al, 2004) and pifithrin at $20 \mu \mathrm{M}$ (Zeng et al, 2007). Treatment with MNU was for $2 \mathrm{~h}$ in all cases: apart from the colony assays, where different concentrations were used, all other experiments used $2 \mathrm{~mm}$ MNU. For 6TG (Sigma), medium was changed every $48 \mathrm{~h}$ with the drug present throughout. For hydroxyurea (Invitrogen, Paisley, UK), cells were treated at $5 \mathrm{~mm}$ for $72 \mathrm{~h}$ (Jiang et al, 1999).

\section{Stable RNAi vector assembly and transfection}

An siRNA oligonucleotide MLH1-1733 5'-AACTGTTCTACCAGA TACTCATT- $3^{\prime}$ was designed for MLH1 using an algorithm (Yuan et al, 2004; available at http://jura.wi.mit.edu). Overlapping primers incorporating the siRNA sequences were made and ligated into pSilencer (Ambion, Huntingdon, UK) as per the supplier's recommendations. All constructs were verified by sequencing. The vector was linearised (SalI) and $1 \times 10^{7}$ cells electroporated (BioRad GenepulserII; Bio-Rad Laboratories Inc., Hemel Hempstead, UK) with $1 \mu \mathrm{g}$ of construct in PBS at $320 \mathrm{~V}$ and $500 \mu \mathrm{F}$. Medium containing serum was immediately added and the cells plated on $90 \mathrm{~mm}$ dishes at $5 \times 10^{5}$ cells per dish before selection in hygromycin $\left(150 \mu \mathrm{g} \mu \mathrm{l}^{-1}\right)$ for 10-14 days.

\section{Western blotting}

Total protein $(30 \mu \mathrm{g})$ from cells growing in log phase was resolved by SDS-PAGE, electroblotted onto nitrocellulose membranes and blocked for $2 \mathrm{~h}$ at room temperature (RT) in $5 \%$ non-fat dry milk. Membranes were incubated with anti-MLH1 (BD Pharmingen; G168-15, Oxford, UK), anti- $\beta$-actin (Abcam; 8226, Cambridge, UK), anti-PMS2 (BD Pharmingen; A16-4), antiGAPDH (Cell Signaling Technologies; 14C10, Herts, UK), anti-Caspase 7 (Cell Signaling Technologies; 9492), anti-PARP (BD Pharmingen; 4C10-5) or anti-PAR (BD Pharmingen; LP96-10) overnight at $4{ }^{\circ} \mathrm{C}$, followed by HRP-conjugated secondary antibody for $2 \mathrm{~h}$ at RT before detection using ECL (Amersham Biosciences, Amersham, UK).

Table I Primer sequences and PCR product sizes for RT-PCR

\begin{tabular}{llc}
\hline Gene & Primers & Product size (bp) \\
\hline MLHI & F: 5'-TGGGACGAAGAAAAGGAATG -3' & 250 \\
& R: 5'-GATCAGGCAGGTTAGCAAGC-3' & 430 \\
MSH6 & F: 5'-GCACGAGTGGACAGACTG-3' & \\
& R: 5'-CGGGTATCAGACCTTCCTG-3' & 713 \\
PMSI & $\begin{array}{l}\text { F: 5'-CACTTCGGTGGTCAGTGTTG-3' } \\
\text { P: 5'-GATGAAACTTCTTCTGGTGTT-3' }\end{array}$ & \\
PMS2 & F: 5'-CCCATGGTAGAAAAGCAGC-3' & 533 \\
& R: 5'-GCGAGATAAGTGGGTGAG-3' & \\
MSH2 & F: 5'-GCTGGAAATAAGGCATCCA-3' & 441 \\
& R: 5'-CATCTGCTCTCCCTITTG-3' & \\
ACTB & F: 5'-AACTGGAACGGTGAAGGTG-3' & 350 \\
& R: 5'-TCAAGTTGGGACAAAAG-3' & \\
\hline
\end{tabular}




\section{Quantitative PCR and reverse transcriptase-PCR}

Total RNA was extracted using the RNeasy kit (Qiagen, Crawley, UK) and cDNA made using oligo $\mathrm{d}(\mathrm{T})_{15}$ and reverse transcriptase (Promega, Southampton, UK). The Taqman gene expression assay kit was used for quantitative PCR (QPCR) of MLH1 (Applied Biosystems, Warrington, UK) with preincubation at $95^{\circ} \mathrm{C}$ for $10 \mathrm{~min}$, then $40 \times 95^{\circ} \mathrm{C}$ for $15 \mathrm{~s}$ and $60^{\circ} \mathrm{C}$ for $1 \mathrm{~min}$. MLH1 values were normalised to GAPDH. The $2^{-\triangle \Delta C T}$ method (Bustin, 2000) was used to quantify the fold difference in $M L H 1$ expression between WT and knockdown and the assay repeated three times. PCR was carried out on cDNA using 1.25 $\mathrm{U}$ Taq, $1 \times$ buffer, $3.5 \mathrm{~mm} \mathrm{MgCl}_{2}, 0.4 \mathrm{~mm}$ dNTPs and 0.5 pmol primer (Invitrogen) at $94^{\circ} \mathrm{C}$ for $3 \mathrm{~min}$, then $25 \times 94^{\circ} \mathrm{C}$ for $1 \mathrm{~min} ; 60^{\circ} \mathrm{C}$ for $1 \mathrm{~min} ; 68^{\circ} \mathrm{C}$ for $1 \mathrm{~min}$ and finally $72^{\circ} \mathrm{C}$ for $10 \mathrm{~min}$. For primer sequences and product sizes see Table 1 .

\section{Cell viability and senescence assays}

TUNEL staining was done using the in situ Cell Death Detection Kit (Roche, Burgess Hill, UK) following the manufacturer's instructions and counterstaining with DAPI $\left(125 \mathrm{ng}^{-1} \mathrm{l}^{-1}\right)$. An ethidium bromide/acridine orange staining technique visualised cells which were undergoing late apoptosis or necrosis (Ribble et al, 2005), which appear red in both cases. Slides were prepared in duplicate and three independent experiments performed. For senescence associated $\beta$-galactosidase assays, $1 \times 10^{5}$ cells per well were seeded on six-well plates and allowed to attach overnight, followed by MNU treatment. Number of senescing cells was determined as described (Rambhatla et al, 2002); as a positive control the solution was buffered to $\mathrm{pH} 4$ to detect non-specific lysosomal $\beta$-galactosidase activity.

\section{Cell cycle profile analysis}

$1 \times 10^{6}$ cells in log phase were harvested, resuspended in $2 \mathrm{ml}$ icecold $70 \%$ ethanol and stored at $-20^{\circ} \mathrm{C}$ for a minimum of $30 \mathrm{~min}$. They were then centrifuged at $300 \mathrm{~g}$ for $5 \mathrm{~min}$, resuspended in $400 \mu \mathrm{l}$ PBS and passed through a 25-gauge needle. To this, $50 \mu \mathrm{l}$ of $1 \mathrm{mg} \mathrm{ml}^{-1}$ RNase and $50 \mu \mathrm{l}$ of $400 \mu \mathrm{g} \mathrm{ml}^{-1}$ propidium iodide was added. This was incubated for $30 \mathrm{~min}$ in the dark at $37^{\circ} \mathrm{C}$ and placed on ice before counting on a Becton Dickinson (Oxford, UK) FACScalibur II.

\section{Microsatellite mutation rate analysis}

The fluctuation analysis was performed as previously described (Roques et al, 2001) with the number of revertants in each subculture corrected for colony-forming efficiency. Mutation rates were calculated using the Luria-Delbruck method of the mean and statistical analysis was as described (Roques et al, 2001).

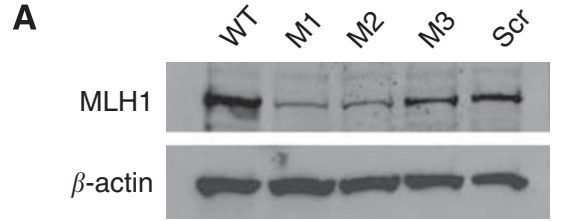

B

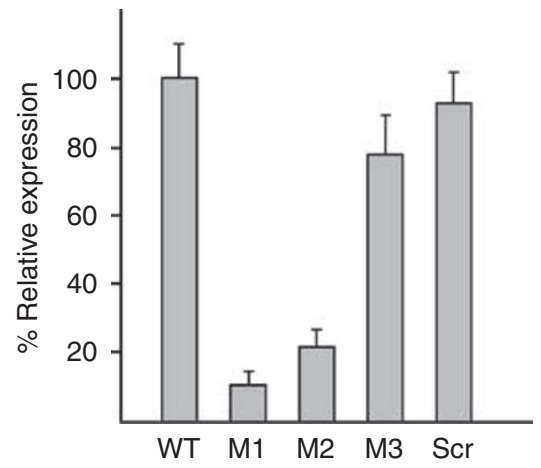

C

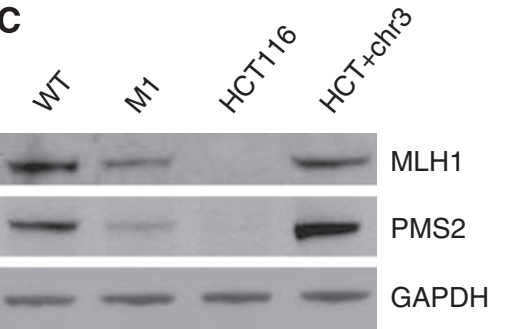

E
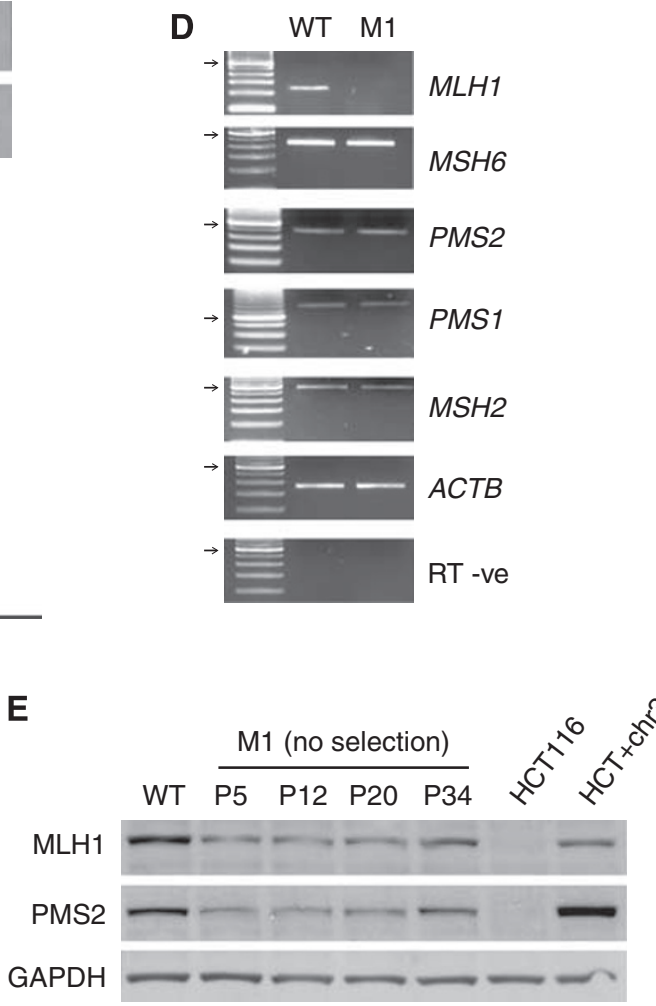

Figure I MLHI depletion in the hTERT-I604 human fibroblast cell line. (A) Western blot of total protein from the parental hTERT-I604 cells used for the transfections (WT) and the clonally derived cell lines MI, M2 and M3 each containing a stably integrated MLHI siRNA vector. Scr denotes cells which contain a scrambled siRNA as negative control. Antibodies used are indicated at left: $\beta$-actin is a loading control. (B) Quantitative PCR (QPCR) showing MLHI transcription levels in clones compared to WT. Samples were normalised to GAPDH and values represent the mean of each experiment \pm 2 standard deviations (s.d.). RNA from the cell with the scrambled control $(\mathrm{Scr})$ is the negative control. (C) Western blot from the indicated cell lines. The same membrane was probed in succession for each of the antibodies at right. A colon cancer cell line lacking MLHI (HCTII6) and the derived cell line HCTII6 + chr3 containing MLHI (HCT + chr3) are shown as controls: GAPDH is a loading control. (D) RT-PCR for each of the MMR genes indicated in $\mathrm{WT}$ and $\mathrm{MI}$ cells. $\beta$-Actin (ACTB) and a reverse transcriptase negative (RT-ve) sample are positive and negative controls, respectively; the arrow indicates the $500 \mathrm{bp}$ band on the size ladder. (E) Western blot of protein extracts from MI cells grown in the absence of hygromycin (no selection): passage number $(P)$ is indicated. Controls are as in $(\mathbf{C})$. The experiments in $(\mathbf{A}-\mathbf{D})$ were carried out at least three times and experiment $(\mathbf{E})$ twice. 


\section{Clonogenic assays for drug resistance}

Cells were seeded at 500 cells per $100 \mathrm{~mm}$ dish and after recovery for $24 \mathrm{~h}$ were treated with drugs as indicated above. After 14 days, plates were stained with crystal violet and colonies counted; numbers were expressed as a percentage of the colonies formed in the absence of the drug. Assays were carried out in triplicate and three independent experiments were completed.

\section{Immunofluorescence}

Gelatin-coated superfrost slides (BDH, Poole, UK) were sterilised by UV overnight, placed in quadriPERM chamber dishes (Sigma), seeded with $5 \times 10^{5}$ cells and then left overnight again. Drug treatment was as described above. Slides were washed for $3 \times 5 \mathrm{~min}$ in PBS and fixed for $15 \mathrm{~min}$ in $4 \%$ ice-cold paraformaldehyde, then washed $3 \times 5 \mathrm{~min}$ in $\mathrm{AB}$ buffer ( $1 \%$ triton $\mathrm{X}-100,4 \%$ goat serum, $0.2 \%$ SDS in PBS). Blocking and permeabilisation was in AB buffer for $3 \mathrm{~h}$ before incubation overnight with mouse anti-phospho $\mathrm{H} 2 \mathrm{AX}$ antibody (Upstate, Watford, UK) at 1:300 dilution, or with rabbit antiapoptosis inducing factor (Cell Signaling Technologies) at $1: 150$ in $\mathrm{AB}$ buffer at $4{ }^{\circ} \mathrm{C}$. Slides were then rinsed in $\mathrm{AB}$ buffer, $3 \times 5 \mathrm{~min}$ and incubated with goat anti-mouse or anti-rabbit Alexa Fluor 488 (Molecular Probes, Eugene, OR, USA) at $1: 400$ for $1 \mathrm{~h}$ at $\mathrm{RT}$, then rinsing as before. Counterstaining was with Hoescht DNA stain (Sigma) before mounting in Vectashield. Images were captured on a Two-photon Laser Scanning Microscope (Leica, Milton Keynes, UK). Experiments were carried out three times; pictures taken are representative of each slide at each time point.

\section{Statistical analysis}

Results, unless noted, are presented as mean \pm standard deviation (s.d.) for a given number of observations $(n)$. Data from each set of observations were cross-compared using unpaired Student's $t$-tests (GraphPad Prism software, GraphPad Software Inc., La Jolla, CA, USA). Differences were considered significant if $P<0.05$.

\section{RESULTS}

\section{Initial characterisation of fibroblast cell lines depleted in MLH1}

Human hTERT-1604 fibroblast cells (WT) were transfected with a vector expressing an siRNA specific for $M L H 1$ and individual resistant colonies picked following growth in hygromycin. Western blotting was used to determine the MLH1 protein levels. Clones varied in the extent of MLH1 depletion, presumably because of insertion site effects. Two clones with low (M1 and M2) and one with intermediate (M3) levels of MLH1 protein were analysed further (Figure 1A), together with cells transcribing a scrambled control (denoted Scr). Real-time PCR was carried out to confirm that the decrease in MLH1 was due to reduced mRNA levels and not an effect on translation and to provide accurate quantitation: levels in M1 (11.6\%) and M2 (22.2\%) were substantially decreased compared to wild type (Figure 1B), whereas those in M3 cells were intermediate to high (78.5\%), with Scr cells (93.30\%) essentially wild type (WT).

PMS2 forms the MutL $\alpha$ repair complex with MLH1 and requires MLH1 binding for stability $(4,27)$. M1 cells showed decreased PMS2 levels as seen in the MLH1-deficient cell line HCT116 (Figure 1C). Levels of PMS2 in M2 and M3 clones were comparable to those of MLH1 in those cells (not shown). To ensure that there was no non-specific targeting of PMS2 or other repair components by the siRNA, we carried out reverse transcriptase-PCR (Figure 1D) which shows that transcript levels for MSH6, PMS2, PMS1 and MSH2 were unaffected.

To ensure that the clones identified are indeed depleted in MLH1 because of the presence of the siRNA and not due to picking
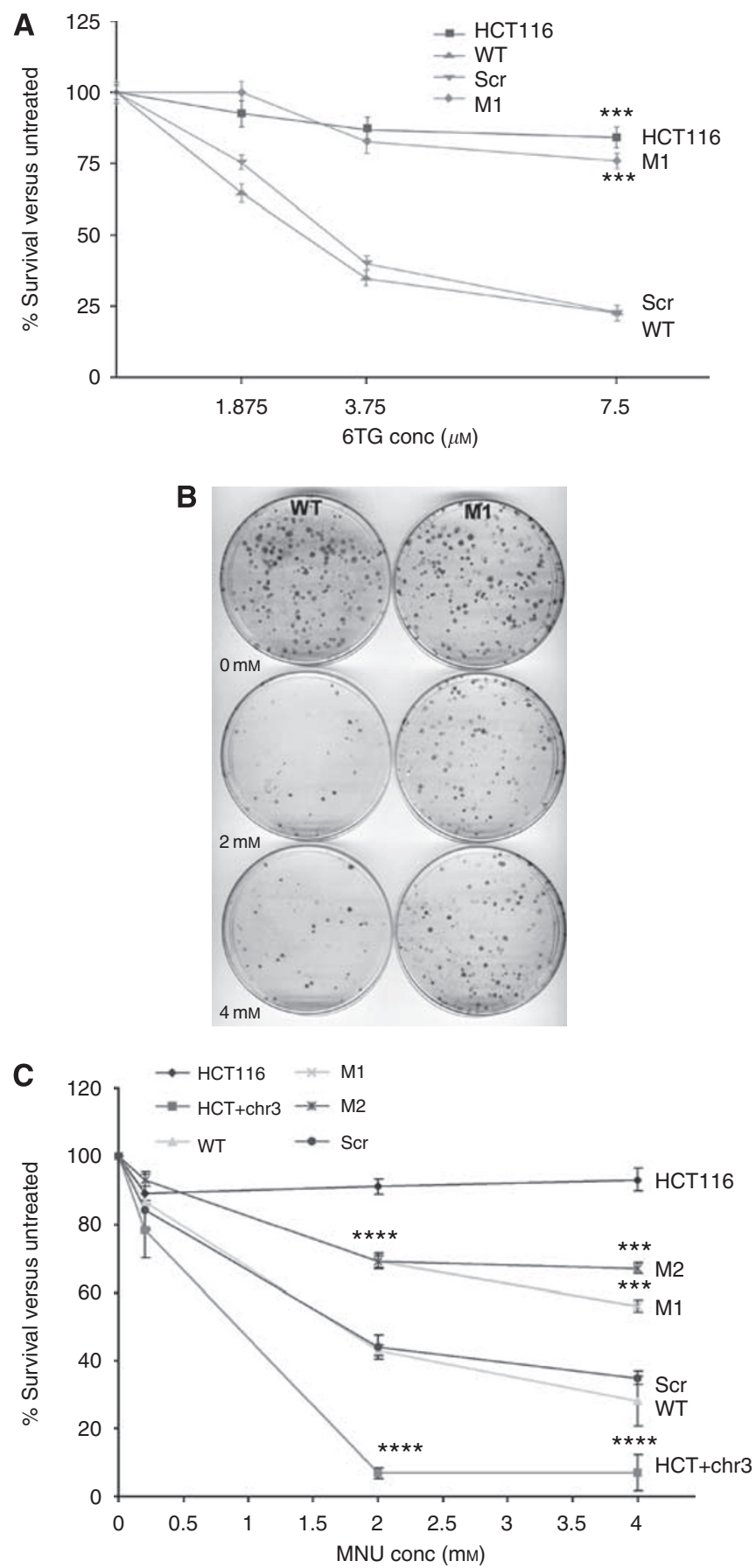

Figure 2 Drug resistance in MLHI-depleted cells. (A) Summary of clonogenic assay results in response to 6TG. A total of 500 cells were seeded on each plate and exposed to the indicated concentrations of the drug for 14 days. Plates were stained and the number of colonies formed expressed as a percentage of the number seen on an untreated plate. Values represent the mean of two independent experiments with two plates per cell line: error bars indicate \pm s.d. HCTI I 6 is a positive control. $\mathrm{MI}$ and HCTII 6 survival at $7.5 \mu \mathrm{M}$ was compared to $\mathrm{WT}$; $* * * P<0.00 \mathrm{I}$. (B) Examples of clonogenic assay plates for WT (left) and MI (right) cells following exposure to the indicated levels of MNU. (C) Summary of clonogenic assays in response to MNU. HCTII6 is a positive control; $\mathrm{HCT}+\mathrm{chr} 3$ and $\mathrm{Scr}$ are negative controls. Statistical comparisons are between matched cell lines (HCTII6 vs HCT + chr3 or WT vs MI etc). Values represent the mean of three independent experiments, each with three plates per cell line: error bars indicate \pm s.d.; **** $P<0.00$ I; ****** $P<0.000 \mathrm{I}$. MI and M2 gave similar $P$ values at $2 \mathrm{mM}$ MNU. The $\mathrm{Scr}$ cells were not significantly different from WT. 
rare clones with mutations in MLH1 or genes which regulate it, we carried out long-term culturing of M1 cells in the absence of selection for the knockdown construct. This led to a gradual increase in MLH1 levels due a slight growth advantage for cells which have turned off siRNA expression. By passage 34 in the absence of hygromycin, MLH1 levels were significantly higher (Figure 1E), showing that MLH1 depletion can be reversed. This was accompanied by increased PMS2 levels, thus restoring the MutL $\alpha$ complex (Figure 1E); these cells were termed M1-R (for 'rescue').

\section{MLH1-deficiency increases cell survival in response to 6TG and $\mathrm{MNU}$}

Resistance to 6TG is characteristic for cell lines lacking MLH1, and M1 cells were as tolerant to $6 \mathrm{TG}$ as HCT116 cells by clonogenic assay (Figure 2A). To test the tolerance of the different MLH1depleted lines to methylating agents, we exposed the cultures to MNU. WT cells were sensitive to MNU only in the presence of BG, which inhibits the endogenous MGMT activity, confirming that the main cytotoxic lesion being caused by the drug was $0^{6}$-methylguanine (Hickman and Samson, 2004). Figure 2B shows typical results for MNU treatment in the presence of the inhibitor, clearly illustrating the increased relative survival of the M1 cells. Results for all the cell lines for MNU are summarised in Figure 2C: resistance was similar in M1 and M2 cells, but the scrambled control was indistinguishable from WT. M1-R cells showed similar drug resistance as WT cells (not shown).

Previous studies have indicated that small amounts of MLH1 are enough for normal repair of microsatellites, whereas much higher levels of this protein are required for damage signalling to be functional (Buermeyer et al, 1999; Cejka et al, 2003). We found the same to be true of our MLH1-depleted cell lines. To test mutation rates, we carried out a Luria-Delbruck fluctuation test (Supplementary Figure 1A) in the M1 cell line, taking advantage of a (CA) 17 microsatellite reporter with a downstream neo gene in the $(-1)$ reading frame which was inserted in the WT cells (Roques et al, 2001). The neo gene can be brought back in frame by deletion of a single repeat $(-2 \mathrm{bp})$ or insertion of two repeats $(+4 \mathrm{bp})$ in the microsatellite, though larger insertions/deletions are possible. The types of mutations were determined by capillary electrophoresis of fluorescently labelled PCR products (Supplementary Figure 1B). Overall, the microsatellite mutation rates were not significantly different between the M1, WT and Scr cells (Table 2). The relative frequencies of the different type of mutations seen are also summarised in Supplementary Figure $1 \mathrm{C}$ and suggest no change in the mutational spectrum in M1 cells. These results confirm that the effects we are seeing in M1 cells are due to the loss of the damage signalling function of MLH1 only, as there is no discernable difference in microsatellite repair function compared to WT cells.

\section{Absence of initial cell cycle arrest in response to $\mathrm{MNU}$ in WT hTERT-immortalised cells}

For most mouse fibroblast or human cancer cell lines, exposure to methylating agents leads to $\mathrm{G}_{2} / \mathrm{M}$ arrest after two cell divisions and in an MLH1-dependent manner (Hawn et al, 1995; Aquilina et al, 1999; Buermeyer et al, 1999). WT fibroblasts did not arrest out to $96 \mathrm{~h}$ (Figure 3A), however, at doses of MNU which gave significant differences in survival (see Figure 2A and B). We could confirm MLH1-dependent cell cycle arrest by $48 \mathrm{~h}$ in HCT116 and HCT116 + chr3 (Figure 3A), where the MLH1 ${ }^{+}$cells arrest in the second cell cycle after exposure (Cejka et al, 2003; Stojic et al, 2004), whereas the MLH1-deficient HCT116 do not. Similar results were found for 6TG: HCT116 + chr3 arrested, but WT did not. M1 cells, like WT cells, did not arrest for either drug (not shown). All experiments were repeated at least three times. Telomeraseimmortalised fibroblasts have previously been shown to have normal cell cycle arrest in response to various insults (Jiang et al, 1999; Vaziri et al, 1999; Ouellette et al, 2000) and we could confirm that the cells have an intact $\mathrm{G}_{2} / \mathrm{M}$ checkpoint, as they arrest at this point in response to depletion of DNMT1 (Figure 3A; Chen et al, 2007). They also show $G_{1}$ accumulation (Supplementary Figure $2 \mathrm{~A}$ ) in response to 5-hydroxyurea (Jiang et al, 1999). Some cancer cells can enter senescence with only transient arrest in response to methylating agents (Hirose et al, 2001, 2002) and hTERTimmortalised cells can exit the cell cycle and enter senescence in response to stresses such as serum deprivation (Hirose et al, 2002; Rambhatla et al, 2002), but we found no increase in the number of senescing cells in response to MNU (Supplementary Figure 2B).

\section{WT cells show a strong MLH1-dependent H2AX phosphorylation response to MNU exposure}

Mismatch repair-coupled processing of methylation damage leads to single-strand DNA breaks, which become sites for $\mathrm{H} 2 \mathrm{AX}$ phosphorylation (Cejka et al, 2003; Mojas et al, 2007). This can be seen in HCT116 + chr3 cells, which show stronger and more persistent $\mathrm{H} 2 \mathrm{AX}$ phosphorylation by $48 \mathrm{~h}$ (Figure 3B) than HCT116, as reported previously (Cejka et al, 2003; Mojas et al, $2007 ; 12,24,48$ and $72 \mathrm{~h}$ time points also examined; data not shown). WT cells also showed phosphorylation of H2AX at $48 \mathrm{~h}$ (Figure $3 \mathrm{~B}$ ), indicating that the cells are indeed detecting the MNU-induced damage in a similar timeframe to the colon cancer cells. Signalling in the WT fibroblasts appeared more widespread

Table 2 Rate of mutation of reporter (CA) 17 repeat in MLHI-depleted cells (MI) and controls

\begin{tabular}{|c|c|c|c|c|}
\hline Cell line & $\begin{array}{l}\text { Mean cloning } \\
\text { efficiency }\end{array}$ & $\begin{array}{l}\text { Mean G4I } 8 \text { resistant } \\
\text { colonies per plate }\end{array}$ & $\begin{array}{l}\text { Proportion of colonies with } \\
\text { microsatellite frameshifts }\end{array}$ & $\begin{array}{c}\text { Microsatellite mutation rate } \\
\text { (mutations per cell per generation) }\end{array}$ \\
\hline & 0.51 & 5 & । & $1.11 \times 10^{-5}$ \\
\hline \multirow[t]{3}{*}{ WT } & 0.52 & 9 & I & $1.56 \times 10^{-5}$ \\
\hline & 0.48 & 11 & 0.81 & $1.78 \times 10^{-5}$ \\
\hline & 0.39 & 20 & 0.77 & $6.64 \times 10^{-6}$ \\
\hline \multirow[t]{3}{*}{$\mathrm{MI}$} & 0.49 & 14 & 0.95 & $1.78 \times 10^{-5}$ \\
\hline & 0.48 & 16 & | & $5.63 \times 10^{-5}$ \\
\hline & 0.5 & 4 & 1 & $9.2 \times 10^{-6}$ \\
\hline \multirow[t]{2}{*}{ Scr } & 0.56 & 9 & i & $1.15 \times 10^{-5}$ \\
\hline & 0.51 & 6 & 0.9 & $1.4 \times 10^{-5}$ \\
\hline
\end{tabular}

For mutation rate analysis, the colony forming efficiency with respect to unselected controls, number of resistant clones, and the fraction of clones with a frameshift in the microsatellite region were determined. Each line represents the respective value for three independent experiments, with median values for the mutation rates indicated in bold. (ie, three replicates $\times$ three independent experiments for WT gave an overall median mutation rate for all nine samples of $1.56 \times 10^{-5}$ ). The difference between the median values for the three groups is not statistically significant ( $M I$ vs $W T, P=0.4705$; $\mathrm{Scr}$ vs $W T, P=0.2468$ ). 
and intense than in HCT116 + chr3, suggesting a stronger response in these normal cells (experiments were repeated three times). M1 cells showed much lower levels of phosphorylation, indicating that
MLH1 depletion prevents normal H2AX signalling in response to MNU in the fibroblasts as well. Confirming that this is due to the absence of MLH1 alone, rescued cells with restored MLH1 levels

A

WT

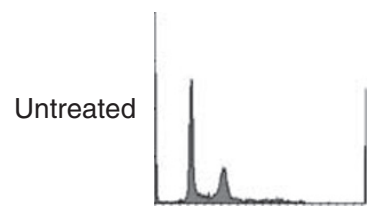

$\mathrm{G}_{1} S \mathrm{G}_{2}$

MNU

$48 \mathrm{~h}$

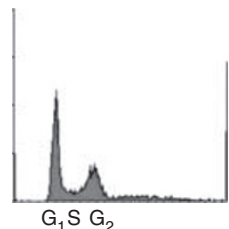

MNU

$48 \mathrm{~h}$

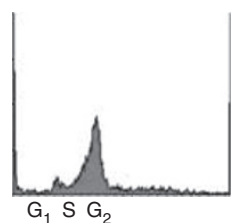

MNU

$96 \mathrm{~h}$

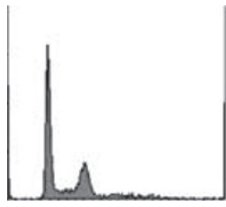

$G_{1} S G_{2}$

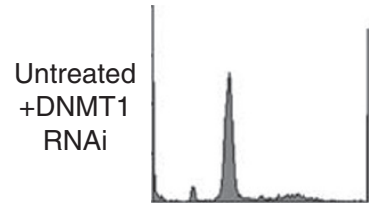

$G_{1} S G_{2}$
Untreated

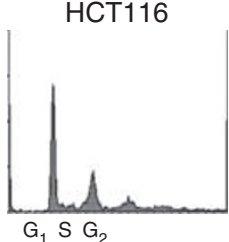

MNU

$48 \mathrm{~h}$
$\mathrm{HCT}+\mathrm{chr} 3$

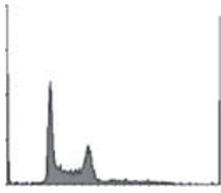

$\mathrm{G}_{1} S \mathrm{G}_{2}$
B
DNA

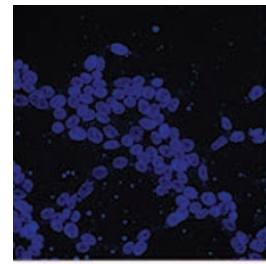

H2A.X
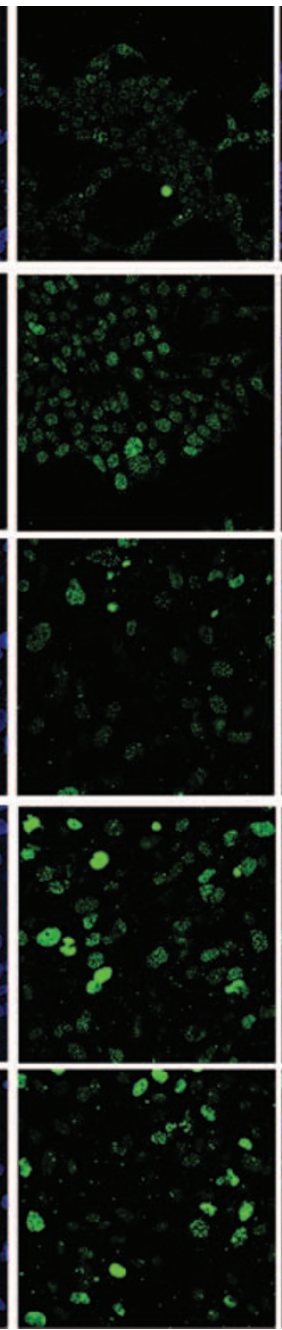

Merge

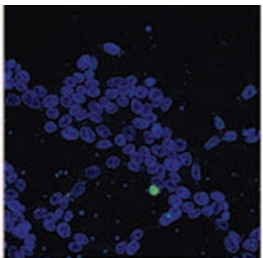

M1

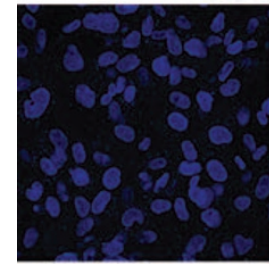

WT
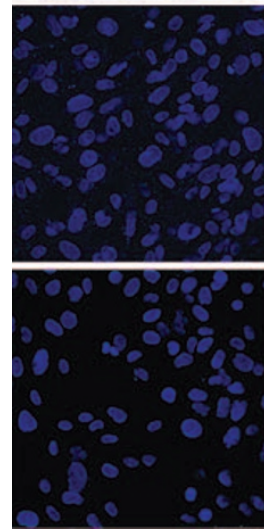

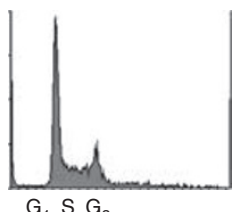

M1-R

Figure 3 Cell cycle profiles and $\mathrm{H} 2 \mathrm{AX}$ signalling in WT and MLHI-depleted cells. (A) Cell cycle profiles. Analysis of WT cells which were exposed to
$2 \mathrm{mM}$ MNU for $2 \mathrm{~h}$ or left untreated, then grown in normal medium, harvested after the indicated time, stained with propidium iodide and analysed by flow cytometry (left). The $G_{1}, S$ and $G_{2} / M$ fractions are indicated. WT cells arrested in $G_{2} / M$ by depletion of DNMTI (DNMTI RNAi) are shown as a control. $\mathrm{HCTI} I 6$ and HCTII $6+$ chr3 (HCT + chr3) are also shown as controls (right). (B) Cells from the cell lines indicated at left were grown on slides and fixed at $48 \mathrm{~h}$ after $2 \mathrm{mM}$ MNU treatment before carrying out immunofluorescence with antibody to the phosphorylated form of histone H2AX (green). DNA was counterstained with Hoescht (blue) to localise the nuclei and images captured on a confocal microscope using identical settings: merged images are shown at right. Experiments were carried out at least three times each.

Figure 4 Differences in PARP activity and in viability between WT and MLHI-depleted cells. (A) Cell viability was assayed using ethidium bromide/ acridine orange staining, which detects both apoptotic and necrotic cells. WT and MI cells were treated with MNU as indicated and numbers of dying cells counted at the times shown. As a control, cells treated with camptothecin were assayed at $72 \mathrm{~h}$. Values represent the mean of three replicates $\pm \mathrm{s}$. $\mathrm{d}$.; *P $<0.05$; ***** $P<0.000 \mathrm{I}$. The experiment was carried out at least three times. (B) WT and MI cells were treated with $2 \mathrm{mM} M N U$ and protein extracted at the indicated times for western blotting with the antibodies shown at left. The asterisk indicates a background band for this antibody also seen in other studies. GAPDH is shown as a loading control. Extracts from cells $48 \mathrm{~h}$ after treatment with staurosporine (STS), which triggers PARP cleavage, are shown for comparison. Experiments were carried out twice. (C) WT or MI cells were seeded onto slides, treated with $2 \mathrm{mM}$ MNU and grown for $48 \mathrm{~h}$ before fixing and examining for nuclear or cytoplasmic localisation of AIF (green) by immunofluorescence on a confocal microscope. DNA was counterstained with Hoescht (blue) and merged images are shown at right. DPQ (30 $\mu \mathrm{M})$ is a PARP inhibitor and Boc-D-FMK (I0 $\mu \mathrm{M})$ a pan-caspase inhibitor. Experiments were carried out three times. (D) Quantitative analysis of the effects of MNU and inhibitors on AIF localisation, based on scoring immunofluoresence staining as seen in (C) for > 100 cells on multiple slides. (E) WT and MI cells were treated with $2 \mathrm{mM} \mathrm{MNU}$, either alone or in combination with $30 \mu \mathrm{M}$ DPQ or I0 $\mu \mathrm{M}$ Boc-D-FMK, and analysed at $72 \mathrm{~h}$ as in $(\mathbf{A})$ above; values represent the mean of three samples \pm s.d.; $* * * * P<0.00$ I; *P $<0.05$; ns, not significant. (F) Clonogenic assays in response to $2 \mathrm{mM} M N U, 30 \mu \mathrm{M}$ DPQ or a combination of the two were carried out on the indicated cell lines with two plates per cell line; error bars indicate \pm s.d. values. The assay was carried out three times for the fibroblasts (WT and MI), with representative results shown, and once for the controls (HCTII6 and HCTII6+ chr3). 
recovered the ability to strongly activate this damage signal (M1-R; Figure 3B).

\section{MLH1-dependent cell death involves activation of PARP,} but not caspases

Cell death can occur in the absence of cell cycle arrest under certain circumstances (Peterson-Roth et al, 2005; Meador et al, 2008). Methylating agents can trigger cell death directly through caspase- (Hickman and Samson, 2004) or PARP-mediated (Yu et al, 2002) pathways. Using acridine orange/ethidium bromide staining we found significant differences in viability by $48 \mathrm{~h}$ between WT and MLH1-depleted cells treated with $2 \mathrm{mM}$ MNU (Figure 4A). We examined PARP activity over time in the MNU-treated cells by western blotting with an anti-PAR antibody (Figure 4B). Increasing numbers of PAR-labelled proteins became visible from 12 to $48 \mathrm{~h}$ in the WT cells, but by $72 \mathrm{~h}$ substrate seemed to have been exhausted as almost no PAR groups were
A

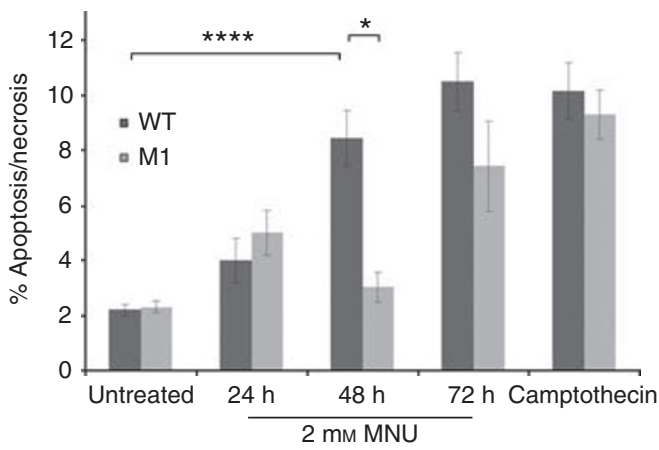

B
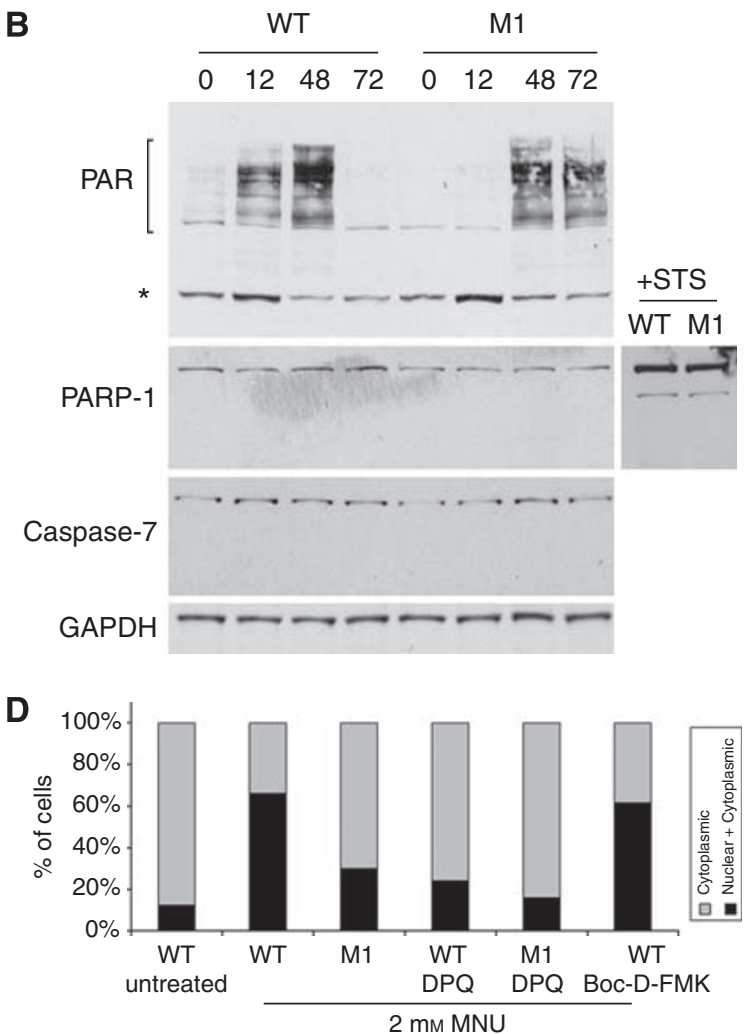

E

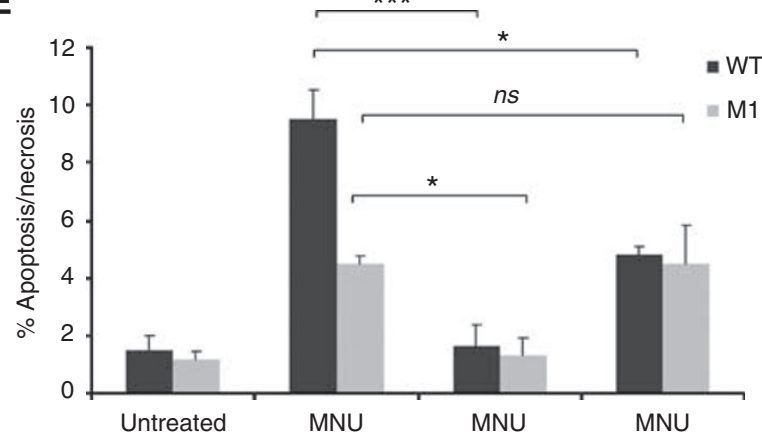

C
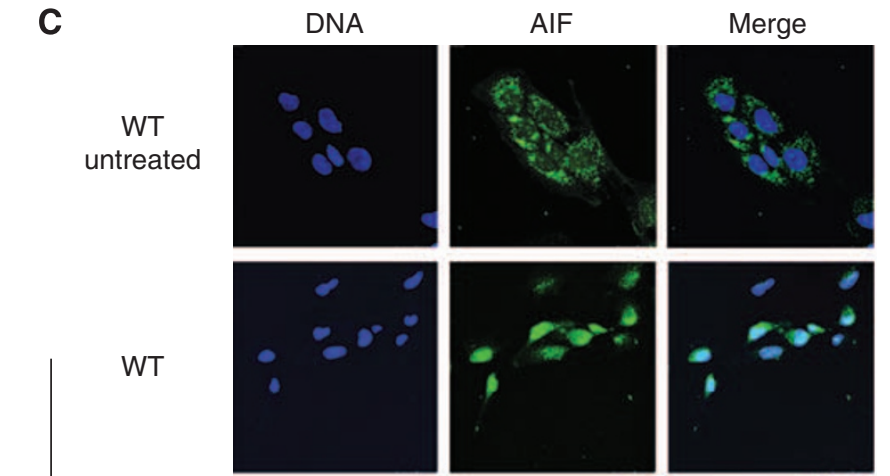

M1
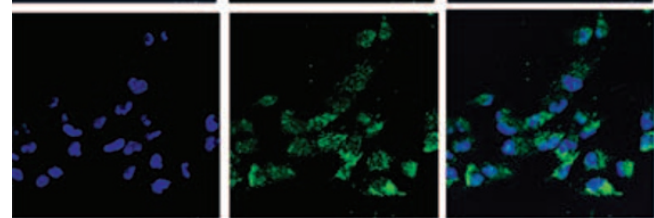

$\underset{\substack{\sum \\ \text { \} }}{\sum}$
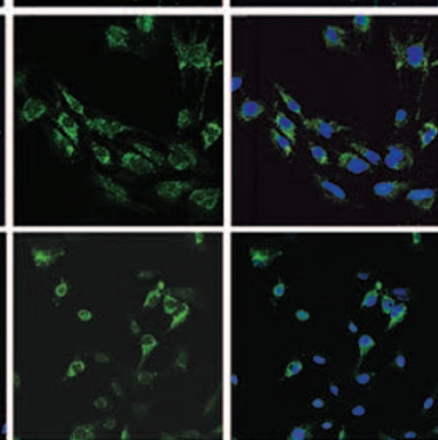

WT

$+\mathrm{DPQ}$
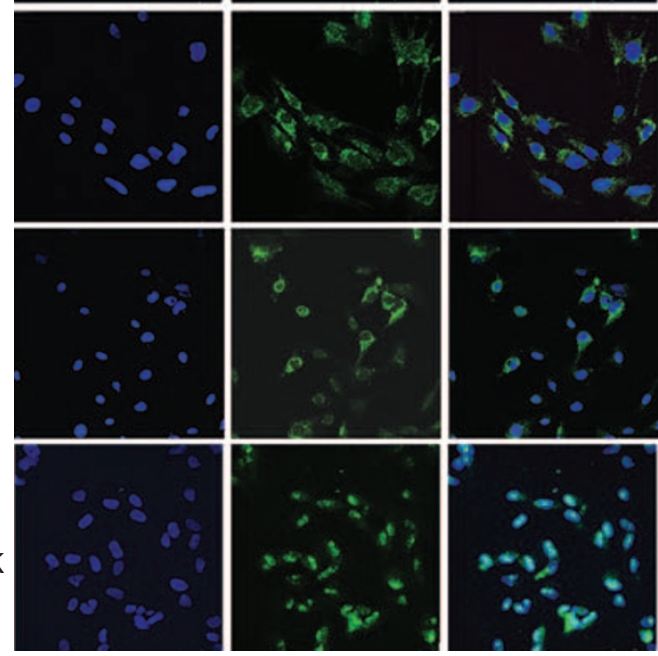

WT

+ Boc-D-FMK

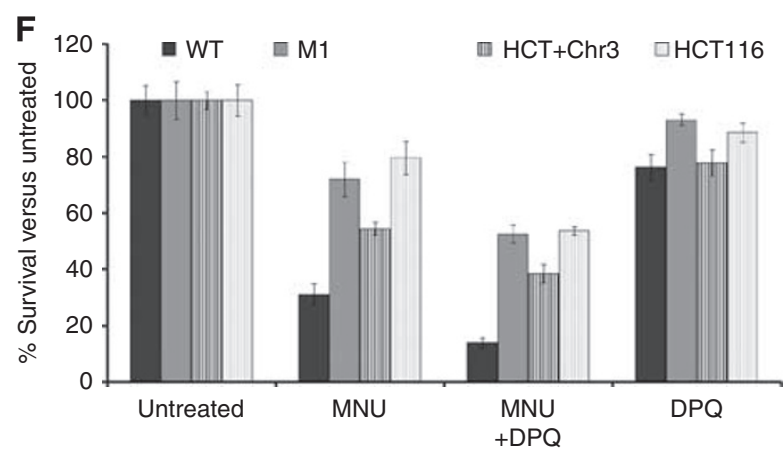


Table 3 Percentage of WT and MLHI-depleted (MI) human fibroblasts undergoing apoptosis in the presence of MNU

\begin{tabular}{lc}
\hline & \% Apoptotic cells ( \pm s.e.m.) \\
\hline DNase treated positive control (WT) & $97.90( \pm 0.9)$ \\
WT & \\
Untreated & $1.51( \pm 0.5)$ \\
$2 \mathrm{mM}$ MNU 12h & $2.50( \pm 0.9)$ \\
$2 \mathrm{mM}$ MNU 24h & $1.48( \pm 0.5)$ \\
MI & \\
Untreated & $1.51( \pm 0.5)$ \\
$2 \mathrm{mM}$ MNU 12h & $1.58( \pm 0.4)$ \\
$2 \mathrm{mM}$ MNU 24h & $1.6( \pm 0.8)$ \\
\hline
\end{tabular}

Cells were seeded on poly-L-lysine slides and apoptosis measured by the TUNEL method. Values shown are the mean percentage \pm s.e.m. of duplicate slides, counting cells in 10 fields at $\times 20$ magnification. Three independent experiments were conducted. The positive control was WT cells treated with DNasel prior to the addition of the terminal deoxynucleotidyl transferase.

detected. In M1 cells however, PAR levels were barely detectable at $12 \mathrm{~h}$, lower than WT at $48 \mathrm{~h}$ and were still easily detectable at $72 \mathrm{~h}$ (Figure 4B). These results suggested that PARP was being activated in response to the MNU-induced damage and that activation depended in part on MLH1. In contrast, no evidence of caspase activation was seen at these time points: targets of caspase cleavage such as caspase-7 and PARP-1 itself remain uncleaved throughout this period (Figure 4B). PARP-1 cleavage in response to staurosporine, a known initiator of caspase-mediated cell death, is shown for comparison. Likewise, we could detect no evidence for TUNEL staining in WT or MLH1-depleted cells during this period (Table 3).

PARP overactivation can lead to translocation of apoptosisinducing factor (AIF) from the mitochondrion to the nucleus ( $\mathrm{Yu}$ et al, 2002, 2006). We examined AIF localisation in WT and MLH1depleted cells (Figure 4C). In untreated WT cells, AIF was present in the cytoplasm in a speckled pattern consistent with its normal mitochondrial localisation; $48 \mathrm{~h}$ after treatment with $\mathrm{MNU}$, most AIF can instead be found in the nucleus of the WT cells. In contrast, $\mathrm{M} 1$ cells show little or no nuclear staining $48 \mathrm{~h}$ after MNU treatment (Figure 4C). To confirm that translocation was dependent on PARP, we treated the WT cells with the PARP inhibitor DPQ as well as MNU: in the presence of DPQ, almost no AIF translocation was seen (Figure 4C). DPQ had no effect on AIF localisation in M1 cells, where it remained cytoplasmic. Substituting a general caspase inhibitor (Boc-D-FMK) instead of DPQ did not block AIF translocation (Figure 4C). Quantitative analysis confirms that MLH1 depletion reduced AIF translocation in response to MNU (Figure 4D) and that translocation is also dependent on PARP, but not caspase activity.

To examine whether inhibiting these events would lead to decreased cell death in response to MNU, we examined cell viability following DPQ treatment. The addition of the PARP inhibitor with MNU led to almost complete abrogation of the short-term effects of MNU on cell viability in both WT and M1 cells (Figure 4E), confirming that MNU initially kills these cells almost exclusively by a PARP-dependent mechanism and that the residual sensitivity to MNU in M1 cells (which may be due to the remaining MLH1) can be overcome by blocking PARP activity. However treatment of cells with DPQ leads to a potentiation of cell killing in response to $2 \mathrm{mM} \mathrm{MNU}$ in a clonogenic assay, compared to treatment with $\mathrm{MNU}$ alone (Figure $4 \mathrm{~F}$ ), as previously reported. This is normally attributed to the detrimental effects of PARP inhibition in the long term on BER-mediated repair of MNUinduced damage, but may also be partly due to its inherent cytotoxicity, evident in cells treated with DPQ alone (Figure $4 \mathrm{~F}$ ).
PARP activation and AIF translocation have been shown to lead to mitochondrial membrane depolarisation, cytochrome $\mathrm{c}$ release and subsequent caspase activation ( $\mathrm{Yu}$ et al, 2002). In keeping with this, we found that caspase inhibitors could partly reduce cell death in the WT cells at $72 \mathrm{~h}$ (Figure $4 \mathrm{E}, P<0.05$ ). Significantly, caspase inhibitors had no protective effect in MLH1-depleted cells, as levels of cell death were unchanged from those seen in cultures treated with MNU alone, suggesting that in the absence of PARPmediated AIF translocation, no caspase activation is occurring.

\section{MLH1, but not ATM/ATR or p53, is required for PARP-mediated cell death in response to MNU}

In colon cancer cells, MLH1 requires ATR (Stojic et al, 2004) and ATM (Adamson et al, 2005) to phosphorylate H2AX and to signal cell cycle arrest, but does not require WT p53 for either process (Cejka et al, 2003); however, MLH1 does require p53 to mediate an autophagic response to 6TG (Zeng et al, 2007). On treating our WT cells with caffeine, an ATM/ATR inhibitor, we found that little H2AX phosphorylation could be detected (Figure 5A). Pifithrin, a p53 inhibitor, gave some reduction in signal, but not as much as in MLH1-depleted cells (Figure 5A).

To determine if inhibiting ATM/ATR would also prevent AIF translocation, we examined protein localisation in caffeine-treated cells. Using a concentration of inhibitor, which effectively blocked H2AX phosphorylation, we still saw AIF translocate to the nucleus in the majority of cells examined (Figure 5B). Likewise, treatment with the p53 inhibitor failed to block AIF movement in response to MNU in most cells, though a fraction of cells showing cytoplasmic retention of AIF was consistently seen (Figure 5B, arrows). In keeping with these results, treatment of WT cells with caffeine or with pifithrin caused a small but not statistically significant decrease in cell death in response to MNU (Figure 5C). As before, the MLH1-depleted cells showed no change in viability in the presence of the ATM/ATR or p53 inhibitors, suggesting that in the absence of MLH1 these cell death mediators are not substantially activated (Figure 5C).

\section{DISCUSSION}

We show here for the first time that reductions in MLH1 levels cause an impairment of PARP-mediated cell death in response to MNU, implicating MLH1 as an important upstream activator of this caspase-independent cell killing mechanism.

In keeping with previous findings (Buermeyer et al, 1999; Cejka et al, 2003), low levels of MLH1 were sufficient to allow maintenance of microsatellite stability in our cell lines but insufficient to trigger a normal damage response to MNU or 6TG. The PARP-dependent cell death pathway, like some other MLH1-mediated responses, therefore requires a higher level of MLH1 protein than that needed for DNA repair.

Our results also show that cell death in response to MNU is not necessarily preceded by $G_{2} / M$ arrest, because our WT cells show no evidence of arrest well past the point at which significant differences in cell signalling and cell survival are evident between the MLH1-proficient and -depleted cells. Direct progression into a cell death pathway without cell cycle arrest has been noted before under some conditions where DNA damage is extensive (Hirose et al, 2002) or H2AX signalling is affected (Meador et al, 2008). The marked difference in the strength of H2AX signalling between our WT fibroblasts and the HCT116+chr3 cells is a possible explanation for the difference between these cell lines with regard to cell cycle response. Previous work by a number of labs has shown that cell cycle arrest in HCT116 + chr3 is dependent on ATR and ATM (Stojic et al, 2004; Adamson et al, 2005); in cells lacking these proteins, $\mathrm{H} 2 \mathrm{AX}$ phosphorylation is reduced and no arrest occurs in response to MNU. ATM and PARP-1 have also been 
A
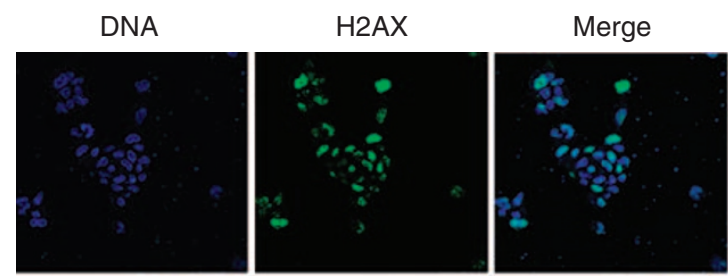

M1
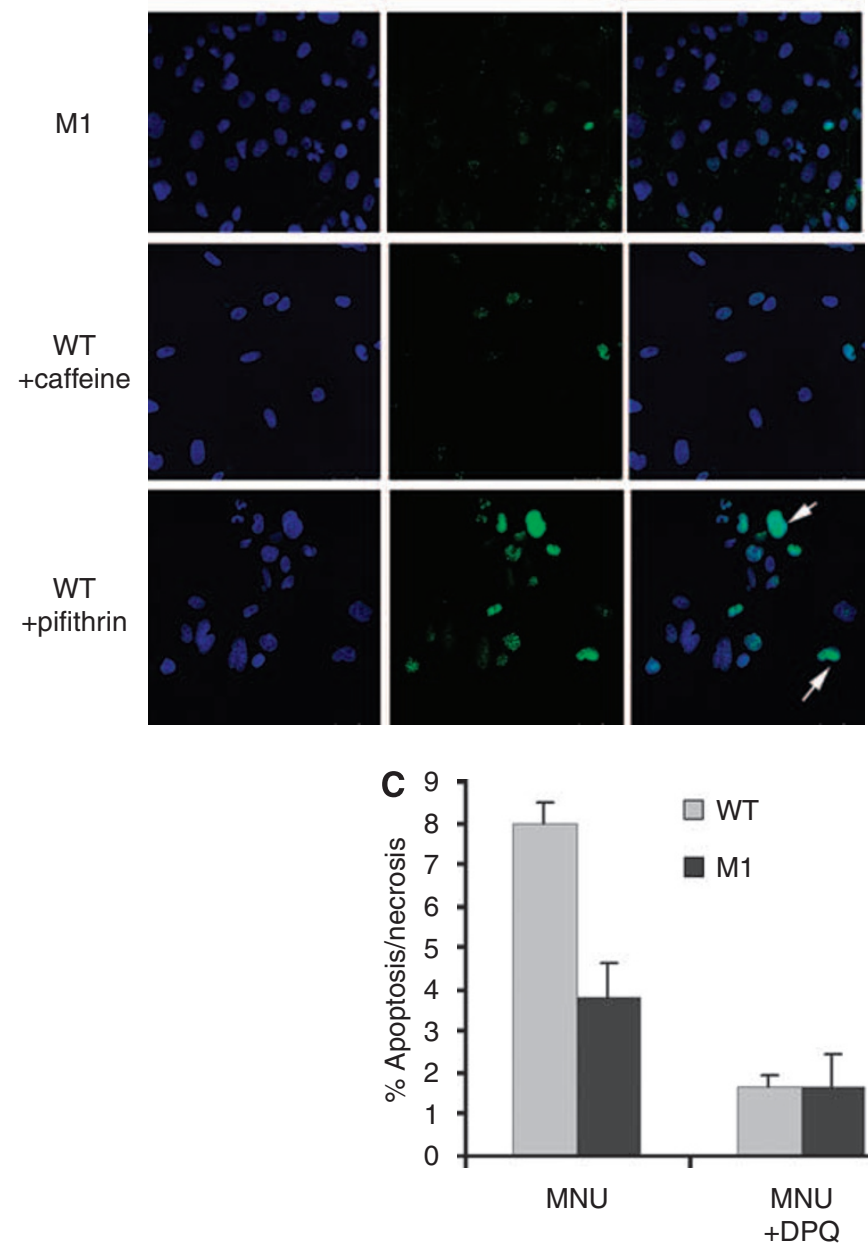

B

WT
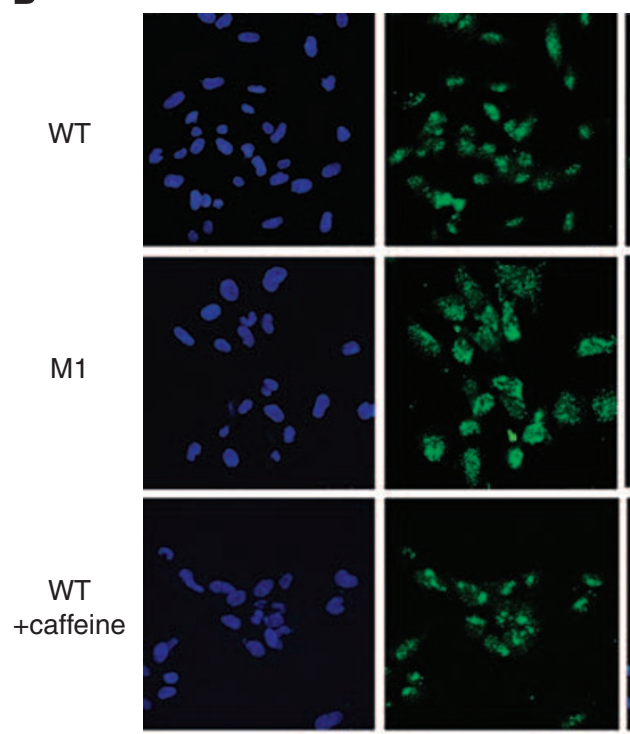

WT

+ pifithrin
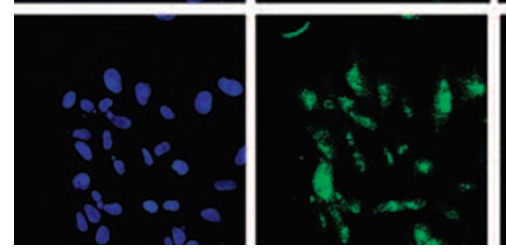

Merge
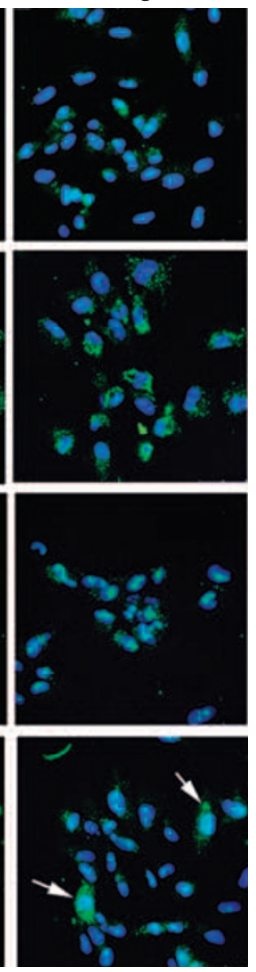

Figure 5 Effects of ATM/ATR and p53 inhibitors on PARP-mediated cell death. (A) H2AX phorphorylation (green) was examined using immunofluoresence: nuclei were counterstained with Hoescht (blue). WT cells were treated with $2 \mathrm{mM} \mathrm{MNU}$ for $2 \mathrm{~h}$ as usual and allowed to recover in the presence or absence of ATM/ATR inhibitor ( $2 \mathrm{mM}$ caffeine) or p53 inhibitor (20 $\mu$ M pifithrin). MI cells are shown for comparison. Images are representative of three independent experiments. Arrows indicate cells showing prominent nuclear staining in the presence of pifithrin. (B) AIF localisation was examined using immunofluoresence to AIF (green) and counterstaining for DNA (blue); WT cells were treated with 2 mM MNU and AMT/ATR inhibitor or p53 inhibitor as indicated in (A). Images are representative of three independent experiments. Arrows indicate cells showing prominent cytoplasmic staining in the presence of pifithrin. (C) Cell viability was assayed following exposure of cells to $2 \mathrm{mM}$ MNU and ATM/ATR inhibitor (caffeine) or p53 inhibitor (pifithrin) as before; values represent the mean of three samples \pm s.d. There were no significant differences in viability in the presence of caffeine or pifithrin.

shown recently to physically and functionally interact following MNNG treatment (Haince et al, 2007). We could confirm that ATM/ATR are also important for H2AX phosphorylation in our cells, but that this signal was not required to trigger PARPmediated cell death, because blocking it could not prevent AIF translocation or increase short-term viability.

The tumour suppressor p53 is a central integrator of stress and cell damage responses and is mutated in almost half of all human cancers. MLH1 triggers an autophagic response to 6TG, but cannot do so if p53 is inactivated (Zeng et al, 2007). However, neither the cell cycle arrest (Cejka et al, 2003) nor the caspase-mediated apoptosis responses (Hickman and Samson, 1999), which MLH1 can invoke in some cells in response to MNU, appear to be p53dependent. We found that blocking p53 gave some reduction in
$\mathrm{H} 2 \mathrm{AX}$ phosphorylation in response to MNU, but failed to prevent AIF translocation or cell death in the majority of cells. These results are consistent with other reports suggesting that the PARPmediated cell death pathway may be partially independent of p53 (Zong et al, 2004; Moubarak et al, 2007).

Differences in H2AX phosphorylation between the WT and MLH1-depleted cells are seen $48 \mathrm{~h}$ after MNU treatment, as for HCT116 and HCT116 + chr3 cells (Cejka et al, 2003; Stojic et al, 2004), and are likely to be developing after the second round of DNA replication. This is the same time point at which PARP activity has peaked in WT fibroblasts and where differences in viability are detectable between WT and MLH1-depleted cells. By $72 \mathrm{~h}$, PARP activity has fallen to zero in WT cells, suggesting $\mathrm{NAD}+$ depletion, which is known to trigger AIF release from the 
mitochondrion (Yu et al, 2002; Zong et al, 2004; Moubarak et al, 2007). PARP activity in the MLH1-depleted cells is first evident at $48 \mathrm{~h}$ at a lower intensity than in WT cells. Consistent with this, we see far higher AIF translocation to the nucleus in WT cells compared to the MLH1-depleted cells at this time. Up to this point, no evidence of caspase activation can be seen: no protein cleavage, TUNEL staining or sub- $G_{1}$ fraction on FACS analysis were detected. AIF translocation has been shown to lead to later cytochrome c release and caspase activation ( $\mathrm{Yu}$ et al, 2002; Moubarak et al, 2007). Our results are also consistent with some late activation of caspase-mediated cell death, but only in cells where MLH1 is at WT levels and can first activate PARP. In a previous study, Samson and colleagues found that although MLH1 was required to activate caspase cleavage in cells treated with a methylating agent, cell death still occurs even in the presence of caspase inhibitors or bcl-2 overexpression (Hickman and Samson, 2004). The data we present here suggest that PARP-mediated AIF translocation is a candidate for the alternative cell death mechanism triggered by methylating agents.

Although the PARP inhibitor DPQ decreased cell death in response to MNU in the short term, it augmented the cell killing effect of MNU in longer-term clonogenic assays. Both of these effects have been well documented before (Tentori et al, 1999; Yu et al, 2002; Curtin et al, 2004; Zong et al, 2004). This apparent paradox can be resolved by considering the types of damage induced by MNU and the two distinct responses, repair or cell death, which can be triggered by PARP in the cell. MNU generates a number of damaged bases in addition to $0^{6}$-methylguanine, mostly $N$-methylpurines, but these latter are promptly dealt with by the base excision repair (BER) system. PARP facilitates BER by catalysing the addition of PAR groups to histones, opening the chromatin for BER access. If levels of damage are too high, PARP becomes overactive and this depletes the cell of NAD, the substrate for PAR, leading to mitochondrial membrane depolarisation and eventual cell death (Yu et al, 2002; Zong et al, 2004). Inhibition of PARP thus can block the early overactivation of the enzyme and NAD depletion, leading to short-term gains in cell viability, but at a cost to BER, the failure of which leads to the independent triggering of cell death in the longer term by adducts such as $\mathrm{N}^{3}$-methyladenine (Engelward et al, 1998). Thus, combining PARP inhibitors with MNU can help to kill MLH1-deficient cells, which are resistant to $0^{6}$-methylguanine, by instead making them sensitive to the $\mathrm{N}$-methylpurine damage. We did not see preferential killing of MLH1-deficient vs MLH1-proficient colon cancer cells (HCT116) or fibroblasts (M1) using DPQ and MNU, as has been reported using temozolomide and second-generation PARP inhibitors such as AG14361 (Curtin et al, 2004) or NU1025 (Tentori et al, 1999). These newer PARP inhibitors have lower cytotoxicity and higher specificity than DPQ, which has nonspecific cytotoxic effects including interference with nucleoside metabolism (Milam et al, 1986) and we show here that it has a detrimental effect on long-term cell survival in the absence of MNU.

MMR deficiency is an important clinical correlate of drug resistance. The use of methylating agents such as temozolomide can give rise to MMR-defective tumours following treatment of ovarian (Brown et al, 1997) and brain tumours (Cahill et al, 2007) and is an independent predictor of poor prognosis after chemotherapy in breast (Mackay et al, 2000) and oesophageal (Kishi et al, 2003) cancer patients. Our data indicate that MLH1deficient cells have a survival advantage against PARP-dependent cell killing through AIF, as well as against caspase-mediated cell death, which was previously known (Hickman and Samson, 1999, 2004). Examining the signalling pathway between MLH1 and PARP may help in the design of strategies for overcoming chemotherapeutic resistance caused by MMR defects. As epigenetic silencing of the MLH1 promoter is commonly seen in tumours showing acquired resistance (Herman and Baylin, 2003), our work also suggests that combining strategies designed to reactivate the silenced MLH1 (such as treatment with DAC; Plumb et al, 2000) with $\mathrm{S}_{\mathrm{N}} 1$ methylating agents may promote PARP-mediated cell death. This independent cell death pathway may be particularly useful in cells where the caspase-mediated route has been blocked due to microsatellite mutations at BAX or ATR (Bacon et al, 2001; Mongiat-Artus et al, 2006). As MLH1 deficiency is sufficient to confer resistance to a range of other clinically relevant chemotherapeutic agents, including cisplatin and 6TG, our model system will be of great use in determining whether MLH1 is involved in signalling PARP in response to these agents as well.

In conclusion, our results show that MLH1 is required to induce a caspase-independent cell death mechanism in response to the $\mathrm{S}_{\mathrm{N}} 1$-type methylating agent $\mathrm{MNU}$. This mechanism is independent of the cell cycle response, ATM/ATR or p53 but is dependent on PARP activation and subsequent AIF translocation.

\section{ACKNOWLEDGEMENTS}

We thank Julie Turbitt for statistical advice, Velma Hayes, Bernie Doherty, Rhonda Black, Patricia Carruthers, Gillian Wasson and Mike Vernon for technical assistance and Mark Lawler, Paul Thompson, Helen Wheadon, Robin Freeburn, Richard Meehan and Bill Kaufmann for valuable comments. Work in CPW's lab was supported by the HPSSNI Cancer RRG, Action Cancer, the BBSRC, Wellcome and a donation in memory of Deirdre Dougan Fitzpatrick and in RAF's lab by NIH grant CA63264.

Supplementary Information accompanies the paper on British Journal of Cancer website (http://www.nature.com/bjc)

\section{REFERENCES}

Adamson AW, Beardsley DI, Kim WJ, Gao Y, Baskaran R, Brown KD (2005) Methylator-induced, mismatch repair-dependent G2 arrest is activated through Chk1 and Chk2. Mol Biol Cell 16: 1513-1526

Amaravadi RK, Thompson CB (2007) The roles of therapy-induced autophagy and necrosis in cancer treatment. Clin Cancer Res 13: $7271-7279$

Aquilina G, Crescenzi M, Bignami M (1999) Mismatch repair, G(2)/M cell cycle arrest and lethality after DNA damage. Carcinogenesis 20: 2317-2326

Bacon AL, Farrington SM, Dunlop MG (2001) Mutation frequency in coding and non-coding repeat sequences in mismatch repair deficient cells derived from normal human tissue. Oncogene 20: 7464-7471

Brown R, Hirst GL, Gallagher WM, McIlwrath AJ, Margison GP, van der Zee AG, Anthoney DA (1997) hMLH1 expression and cellular responses of ovarian tumour cells to treatment with cytotoxic anticancer agents. Oncogene 15: 45-52
Buermeyer AB, Wilson-Van Patten C, Baker SM, Liskay RM (1999) The human MLH1 cDNA complements DNA mismatch repair defects in Mlh1-deficient mouse embryonic fibroblasts. Cancer Res 59: 538-541

Bustin SA (2000) Absolute quantification of mRNA using real-time reverse transcription polymerase chain reaction assays. J Mol Endocrinol 25: $169-193$

Cahill DP, Levine KK, Betensky RA, Codd PJ, Romany CA, Reavie LB, Batchelor TT, Futreal PA, Stratton MR, Curry WT, Iafrate AJ, Louis DN (2007) Loss of the mismatch repair protein MSH6 in human glioblastomas is associated with tumor progression during temozolomide treatment. Clin Cancer Res 13: 2038-2045

Cejka P, Stojic L, Mojas N, Russell AM, Heinimann K, Cannavo E, di Pietro M, Marra G, Jiricny J (2003) Methylation-induced G(2)/M arrest requires a full complement of the mismatch repair protein hMLH1. EMBO J 22: $2245-2254$ 
Chen T, Hevi S, Gay F, Tsujimoto N, He T, Zhang B, Ueda Y, Li E (2007) Complete inactivation of DNMT1 leads to mitotic catastrophe in human cancer cells. Nat Genet 39: $391-396$

Curtin NJ, Wang LZ, Yiakouvaki A, Kyle S, Arris CA, Canan-Koch S, Webber SE, Durkacz BW, Calvert HA, Hostomsky Z, Newell DR (2004) Novel poly(ADP-ribose) polymerase-1 inhibitor, AG14361, restores sensitivity to temozolomide in mismatch repair-deficient cells. Clin Cancer Res 10: $881-889$

Danial NN (2007) BCL-2 family proteins: critical checkpoints of apoptotic cell death. Clin Cancer Res 13: 7254-7263

Duval A, Hamelin R (2002) Mutations at coding repeat sequences in mismatch repair-deficient human cancers: toward a new concept of target genes for instability. Cancer Res 62: 2447-2454

Engelward BP, Allan JM, Dreslin AJ, Kelly JD, Wu MM, Gold B, Samson LD (1998) A chemical and genetic approach together define the biological consequences of 3-methyladenine lesions in the mammalian genome. J Biol Chem 273: 5412-5418

Haince JF, Kozlov S, Dawson VL, Dawson TM, Hendzel MJ, Lavin MF, Poirier GG (2007) Ataxia telangiectasia mutated (ATM) signaling network is modulated by a novel poly(ADP-ribose)-dependent pathway in the early response to DNA-damaging agents. J Biol Chem 282: $16441-16453$

Hawn MT, Umar A, Carethers JM, Marra G, Kunkel TA, Boland CR, Koi M (1995) Evidence for a connection between the mismatch repair system and the G2 cell cycle checkpoint. Cancer Res 55: 3721-3725

Herman JG, Baylin SB (2003) Gene silencing in cancer in association with promoter hypermethylation. $N$ Engl J Med 349: $2042-2054$

Hickman MJ, Samson LD (1999) Role of DNA mismatch repair and p53 in signaling induction of apoptosis by alkylating agents. Proc Natl Acad Sci USA 96: $10764-10769$

Hickman MJ, Samson LD (2004) Apoptotic signaling in response to a single type of DNA lesion, O(6)-methylguanine. Mol Cell 14: 105-116

Hirose T, Kondo K, Takahashi Y, Ishikura H, Fujino $\mathrm{H}$, Tsuyuguchi $\mathrm{M}$, Hashimoto M, Yokose T, Mukai K, Kodama T, Monden Y (2002) Frequent microsatellite instability in lung cancer from chromate-exposed workers. Mol Carcinog 33: 172-180

Hirose Y, Berger MS, Pieper RO (2001) Abrogation of the Chk1-mediated G(2) checkpoint pathway potentiates temozolomide-induced toxicity in a p53-independent manner in human glioblastoma cells. Cancer Res 61: $5843-5849$

Jiang XR, Jimenez G, Chang E, Frolkis M, Kusler B, Sage M, Beeche M, Bodnar AG, Wahl GM, Tlsty TD, Chiu CP (1999) Telomerase expression in human somatic cells does not induce changes associated with a transformed phenotype. Nat Genet 21: 111-114

Kim MY, Zhang T, Kraus WL (2005) Poly (ADP-ribosyl) ation by PARP1:PAR-laying'NAD into a nuclear signal. Genes Dev 19: 1951-1967

Kishi K, Doki Y, Yano M, Yasuda T, Fujiwara Y, Takiguchi S, Kim S, Higuchi I, Monden M (2003) Reduced MLH1 expression after chemotherapy is an indicator for poor prognosis in esophageal cancers. Clin Cancer Res 9: 4368-4375

Koi M, Umar A, Chauhan DP, Cherian SP, Carethers JM, Kunkel TA, Boland CR (1994) Human chromosome 3 corrects mismatch repair deficiency and microsatellite instability and reduces $\mathrm{N}$-methyl- $\mathrm{N}^{\prime}$-nitro$\mathrm{N}$-nitrosoguanidine tolerance in colon tumor cells with homozygous hMLH1 mutation. Cancer Res 54: 4308-4312

Kunkel TA, Erie DA (2005) DNA mismatch repair. Annu Rev Biochem 74: $681-710$

Lavin MF, Birrell G, Chen P, Kozlov S, Scott S, Gueven N (2005) ATM signaling and genomic stability in response to DNA damage. Mutat Res 569: $123-132$

Lister TA (1991) The manangement of follicular lymphoma. Ann Oncol 2(suppl 2): $131-135$

Mackay HJ, Cameron D, Rahilly M, Mackean MJ, Paul J, Kaye SB, Brown R (2000) Reduced MLH1 expression in breast tumors after primary chemotherapy predicts disease-free survival. J Clin Oncol 18: $87-93$

Meador JA, Zhao M, Su Y, Narayan G, Geard CR, Balajee AS (2008) Histone $\mathrm{H} 2 \mathrm{AX}$ is a critical factor for cellular protection against DNA alkylating agents. Oncogene 27: 5662-5671

Milam KM, Thomas GH, Cleaver JE (1986) Disturbances in DNA precursor metabolism associated with exposure to an inhibitor of poly(ADPribose) synthetase. Exp Cell Res 165: 260-268

Mojas N, Lopes M, Jiricny J (2007) Mismatch repair-dependent processing of methylation damage gives rise to persistent single-stranded gaps in newly replicated DNA. Genes Dev 21: $3342-3355$
Mongiat-Artus P, Miquel C, Van der Aa M, Buhard O, Hamelin R, Soliman H, Bangma C, Janin A, Teillac P, van der Kwast T, Praz F (2006) Microsatellite instability and mutation analysis of candidate genes in urothelial cell carcinomas of upper urinary tract. Oncogene 25: 2113-2118

Moubarak RS, Yuste VJ, Artus C, Bouharrour A, Greer PA, Menissier-de Murcia J, Susin SA (2007) Sequential activation of poly(ADP-ribose) polymerase 1, calpains, and Bax is essential in apoptosis-inducing factormediated programmed necrosis. Mol Cell Biol 27: $4844-4862$

O'Brien V, Brown R (2006) Signalling cell cycle arrest and cell death through the MMR System. Carcinogenesis 27: 682-692, doi:10.1093/ carcin/bgi298

Ouellette MM, McDaniel LD, Wright WE, Shay JW, Schultz RA (2000) The establishment of telomerase-immortalized cell lines representing human chromosome instability syndromes. Hum Mol Genet 9: 403-411

Peltomaki P, Vasen H (2004) Mutations associated with HNPCC predisposition - update of ICG-HNPCC/INSiGHT mutation database. Dis Markers 20: 269-276

Peterson-Roth E, Reynolds M, Quievryn G, Zhitkovich A (2005) Mismatch repair proteins are activators of toxic responses to chromium-DNA damage. Mol Cell Biol 25: 3596-3607

Plumb JA, Strathdee G, Sludden J, Kaye SB, Brown R (2000) Reversal of drug resistance in human tumor xenografts by $2^{\prime}$-deoxy-5-azacytidineinduced demethylation of the hMLH1 gene promoter. Cancer Res 60: $6039-6044$

Rambhatla L, Chiu CP, Glickman RD, Rowe-Rendleman C (2002) In vitro differentiation capacity of telomerase immortalized human RPE cells. Invest Ophthalmol Vis Sci 43: 1622-1630

Raschle M, Dufner P, Marra G, Jiricny J (2002) Mutations within the hMLH1 and hPMS2 subunits of the human MutLalpha mismatch repair factor affect its ATPase activity, but not its ability to interact with hMutSalpha. J Biol Chem 277: 21810-21820

Ribble D, Goldstein NB, Norris DA, Shellman YG (2005) A simple technique for quantifying apoptosis in 96-well plates. BMC Biotechnol 5: 12

Roques CN, Boyer JC, Farber RA (2001) Microsatellite mutation rates are equivalent in normal and telomerase-immortalized human fibroblasts. Cancer Res 61: 8405-8407

Stojic L, Mojas N, Cejka P, Di Pietro M, Ferrari S, Marra G, Jiricny J (2004) Mismatch repair-dependent G2 checkpoint induced by low doses of SN1 type methylating agents requires the ATR kinase. Genes Dev 18: 1331 - 1344

Susin S, Lorenzo H, Zamzami N, Marzo I, Snow B, Brothers G, Mangion J, Jacotot E, Costantini P, Loeffler M (1999) Molecular characterization of mitochondrial apoptosis-inducing factor. Nature 397: $441-446$

Tentori L, Turriziani M, Franco D, Serafino A, Levati L, Roy R, Bonmassar E, Graziani G (1999) Treatment with temozolomide and poly(ADPribose) polymerase inhibitors induces early apoptosis and increases base excision repair gene transcripts in leukemic cells resistant to triazene compounds. Leukemia 13: 901 -909

Thibodeau SN, French AJ, Cunningham JM, Tester D, Burgart LJ, Roche PC, McDonnell SK, Schaid DJ, Vockley CW, Michels VV, Farr Jr GH, O'Connell MJ (1998) Microsatellite instability in colorectal cancer: different mutator phenotypes and the principal involvement of hMLH1. Cancer Res 58: $1713-1718$

Vaziri H, Squire JA, Pandita TK, Bradley G, Kuba RM, Zhang H, Gulyas S, Hill RP, Nolan GP, Benchimol S (1999) Analysis of genomic integrity and p53-dependent G1 checkpoint in telomerase-induced extended-life-span human fibroblasts. Mol Cell Biol 19: 2373-2379

Yanamadala S, Ljungman M (2003) Potential role of MLH1 in the induction of p53 and apoptosis by blocking transcription on damaged DNA templates. Mol Cancer Res 1: 747-754

Yu SW, Andrabi SA, Wang H, Kim NS, Poirier GG, Dawson TM, Dawson VL (2006) Apoptosis-inducing factor mediates poly(ADP-ribose) (PAR) polymer-induced cell death. Proc Natl Acad Sci USA 103: 18314-18319

Yu SW, Wang H, Poitras MF, Coombs C, Bowers WJ, Federoff HJ, Poirier GG, Dawson TM, Dawson VL (2002) Mediation of poly(ADP-ribose) polymerase-1-dependent cell death by apoptosis-inducing factor. Science 297: $259-263$

Yuan B, Latek R, Hossbach M, Tuschl T, Lewitter F (2004) siRNA Selection Server: an automated siRNA oligonucleotide prediction server. Nucleic Acids Res 32: W130-W134

Zeng X, Yan T, Schupp JE, Seo Y, Kinsella TJ (2007) DNA mismatch repair initiates 6-thioguanine - induced autophagy through p53 activation in human tumor cells. Clin Cancer Res 13: 1315-1321

Zong WX, Ditsworth D, Bauer DE, Wang ZQ, Thompson CB (2004) Alkylating DNA damage stimulates a regulated form of necrotic cell death. Genes Dev 18: $1272-1282$ 